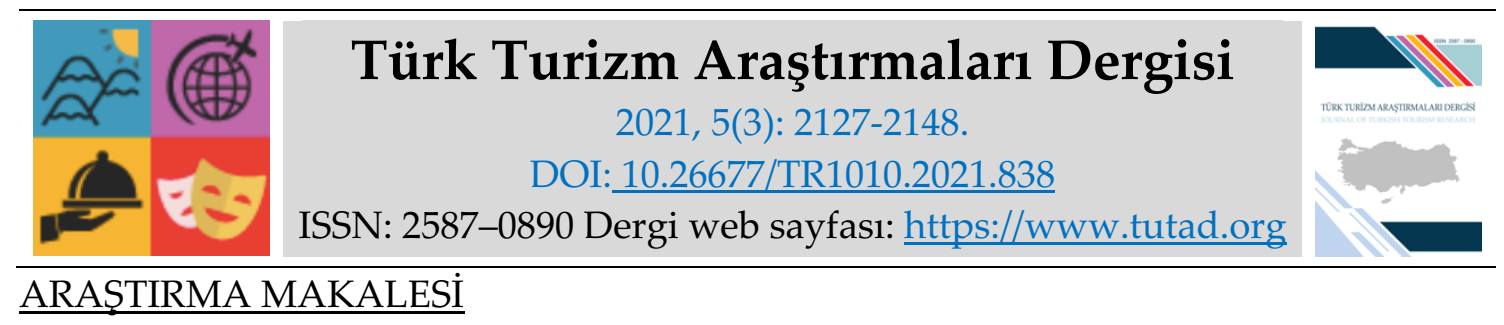

\title{
Konaklama İşletmelerindeki Kadın Çalışanların Kraliçe Arı Sendromu Algılarının Ölçülmesine Yönelik Bir Ölçek Geliştirme Çalışması*
}

Öğr. Gör. Onur ÇELEN, Bursa Uludağ Üniversitesi, Harmancık MYO, Bursa, e-posta: onurcelen@uludag.edu.tr

ORCID: https://orcid.org/0000-0003-4601-2173

Prof. Dr. Muharrem TUNA, Ankara Hacı Bayram Veli Üniversitesi, Turizm Fakültesi, Ankara, eposta: muharrem.tuna@hbv.edu.tr

ORCID: https://orcid.org/0000-0001-5526-7122

\section{Öz}

Çalışmada, Türkiye'nin Trakya Bölümü'nde yer alan Kırklareli, Tekirdağ ve Edirne illeri ile İstanbul ve Çanakkale illerinin sadece Avrupa yakasında faaliyetlerini sürdüren dört ve beş yıldızlı konaklama işletmelerinde çalışan kadınların işletmelerinde algıladıkları "Kraliçe Arı Sendromu" düzeylerinin ölçülmesi ve ilgili kadın çalışanların demografik özellikleri ile "Kraliçe Arı Sendromu" boyutları arasındaki ilişkilerin belirlenmesi amaçlanmaktadır. Belirlenen amaç doğrultusunda "Kraliçe Arı Sendromu" ve boyutlarıyla ilgili literatürde bir ölçek olmadığı fark edilmiş ve konuyla ilgili ölçek geliştirilerek, gerekli testler gerçekleştirilmiştir. Geliştirilen ölçek 2019 yılının Ekim ayında Kırklareli (2 işletme), Tekirdağ (7 işletme), Edirne (2 işletme), Çanakkale (3 işletme) ve İstanbul'da (12 işletme) konaklama işletmelerinde çalışan 134 kadına kendilerinin cevaplandırdıkları anket formu şeklinde ulaştırılmıştır. Analiz sonucunda anket formlarından elde edilen veriler SPSS istatiksel paket programında analize tabi tutulmuştur. Araştırma sonucunda; kadın çalışanların kadınların yönetici olmasını olumsuz değerlendirdikleri, işletmelerinde erkekleri yönetici olarak daha başarılı buldukları, işletmelerinde erkek yöneticilerle çalışmayı daha kolay buldukları, işletmelerdeki kadın yöneticilerin kadın çalışanları engellediğini düşündükleri ve işletmelerinde birden fazla kadın yönetici olmasını desteklemedikleri belirlenmiştir.

* Bu makale çalışması, Ankara Hacı Bayram Veli Üniversitesi Lisansüstü Eğitim Enstitüsü Turizm İşletmeciliği ABD'nda Prof. Dr. Muharrem TUNA danışmanlığında ve Öğr. Gör. Onur ÇELEN tarafından hazırlanan "Kraliçe Arı Sendromunun Örgütsel Bağlılık ve Örgütsel Verimlilik Üzerine Etkisi: Turizm İşletmelerine Yönelik Bir Araştırma" başlıklı doktora tez çalışmasının ön test verilerinden yararlanılarak hazırlanmıştır.

Anahtar Kelimeler: Turizm, Konaklama İşletmeleri, Kraliçe Arı Sendromu, Kadın Çalışanlar, Trakya.

Makale Gönderme Tarihi: 11.07.2021

Makale Kabul Tarihi: 04.09.2021

\section{Önerilen Atıf:}

Çelen, O. ve Tuna, M. (2021). Konaklama İşletmelerindeki Kadın Çalışanların Kraliçe Arı Sendromu Algılarının Ölçülmesine Yönelik Bir Ölçek Geliştirme Çalışması, Türk Turizm Araştırmaları Dergisi, 5(3): 21272148.

(C) 2021 Türk Turizm Araştırmaları Dergisi. 


\title{
Journal of Turkish Tourism Research
2021, 5(3): 2127-2148.
DOI: $10.26677 /$ TR1010.2021.838 \\ RESEARCH PAPER
}

\section{A Scale Development Study to Measure Queen Bee Syndrome Perceptions of Female Employees in Hospitality in Accommodation Establishments}

Lecturer Onur ÇELEN, Bursa Uludağ University, Harmancık Vocational School, Bursa, e-mail: onurcelen@uludag.edu.tr ORCID: https://orcid.org/0000-0003-4601-2173

Prof. Dr. Muharrem TUNA, Ankara Hacı Bayram Veli University, Faculty of Tourism, Ankara, e-mail: muharrem.tuna@hbv.edu.tr ORCID: https://orcid.org/0000-0001-5526-7122

\begin{abstract}
In the study, measuring the levels of "Queen Bee Syndrome" perceived by women working in four- and five-star accommodation businesses operating only on the European side of İstanbul, Çanakkale, Kırklareli, Tekirdağ and Edirne provinces in the Thrace Region of Turkey, and the demographic characteristics of the relevant female employees. and "Queen Bee Syndrome" dimensions. In line with the determined purpose, it was noticed that there is no scale in the literature about queen bee syndrome and its dimensions, and the necessary tests were carried out by developing a scale on the subject. The developed scale was delivered to 134 women working in accommodation businesses in Kirklareli ( 2 businesses), Tekirdağ (7 businesses), Edirne (2 businesses), Çanakkale (3 businesses) and Istanbul (12 businesses) in the form of a questionnaire they answered in October 2019. As a result of the analysis, the data obtained from the questionnaires were analyzed in the SPSS statistical package program. As a result of the research; It has been determined that female employees negatively evaluate women's being managers, they find men more successful as managers in their businesses, they find it easier to work with male managers in their businesses, they think that female managers in businesses prevent female employees and they do not support having more than one female manager in their businesses.
\end{abstract}

Keywords: Tourism, Accommodation Business, Queen Bee Syndrome, Female Employees, Thrace.

Received: 11.07 .2021

Accepted: 04.09.2021

\section{Suggested Citation:}

Çelen, O. and Tuna, M. (2021). A Scale Development Study to Measure Queen Bee Syndrome Perceptions of Female Employees in Hospitality in Accommodation Establishments, Journal of Turkish Tourism Research, 5(3): 2127-2148.

(C) 2021 Türk Turizm Araştırmaları Dergisi. 


\section{Gíriş}

Kadın, toplum içerisinde kardeş, abla, eş, anne, evlat, arkadaş, dost, tüketici vb. rolleri üstlenmektedir. Bu rollerin yanı sıra kadın iş hayatında yönetici ve çalışan olarak yer almaktadır (Davidson ve Burke, 2011). Kadının iş hayatına atılmasına; ekonomik özgürlüğünü elde etme, ailesi için ek gelir sağlama, toplum ve kendi içinde kendini yararlı hissetme, iş ve bireysel anlamda tatmin olma isteği gibi faktörler etki etmektedir (Akşit Aşık, 2014:85). Bu faktörlerin temelinde ise çoğu zaman kadının kendisi için toplum tarafından belirlenmiş geleneksel cinsiyete dayalı rolleri deneyimlemesi yatmaktadır. Örneğin; liderlik hususunda toplum içerisinde oluşturulan kalıp, liderliğin erkeğe daha uygun olduğu şeklindedir. Erkeklerin liderlik ve motivasyon sağlama açısından bu denli güçlü yapıda güdülenmeleri kadınların kendilerini yönetim anlamında yetersiz görmelerine ve çeşitli konularda güven eksikliği duymalarına neden olabilmektedir (Adebayo ve Udegbe, 2004:516). Kadınlar bu ve benzeri durumlardan etkilenerek erkek yöneticilerin kendilerine olan bu yaklaşımı karşısında cam tavan sendromuna yakalanabilmekte veya zorlu mücadeleler sonucunda elde ettikleri makamlarına karşı astları veya denkleri pozisyonundaki diğer kadın çalışanları bir tehdit olarak görebilmektedirler. Literatürde sözü edilen bu tehdit "kraliçe arı sendromu" şeklinde tanımlanmaktadır (Karakuş, 2014: 335). Stanies vd., (1974) tarafından 20.000 kadın çalışanla yürütülen araştırma sonucunda "kraliçe arı sendromu" kavramı literatüre kazandırılmıştır. Kraliçe arı sendromunda liderlik yetisi ve yetkisine sahip olan kadın yöneticinin, meslektaşları olan hemcinslerini eleştirel bir biçimde ele alması, onları tehdit olarak görmesi, onlara karşı olumsuz ve yıkıcı bir tutum göstermesi söz konusudur. Kavram; kariyerinde çeşitli başarılar yakalayan fakat ilgili sendroma bağlı olarak özellikle emrinde çalışan kadınların benzer başarıları göstermelerine onay vermeyen kadınları bir kraliçe arı olarak betimlemektedir (Blau ve DeVaro, 2007:527-528).

Kadın yöneticilerin belirtilen davranışlarda bulunmaları görev aldıkları işletmelerde diğer çalışanların görevleriyle bilişsel ve duygusal anlamda bütünlüğün ve işletmelerin faaliyetlerinde devamlılığın sağlanması hususunda istenmeyen etkilere ve sonuçlara neden olabilmektedir. Bu duruma bağlı olarak işletmelerden ayrılmalar gerçekleşebilmekte ve işletmeye katılan yeni kadın çalışanlara karşı benzer davranışlar sergilenebilmektedir. Çalışanların kendilerini işletmenin bir parçası olarak görmemeleri çalışanların işe bağlılık duymalarında ve sergiledikleri psikolojik davranışları üzerinde negatif etkiye neden olarak işletmelerde verimliliği düşürmektedir (Van Kinppenberg vd., 2007:457). Kadın çalışanların ve yöneticilerin yoğun bir şekilde istihdam edildiği turizm işletmelerinde kraliçe arı sendromunun yaşanması kaçınılmazdır. Kraliçe arı sendromu ile ilgili daha önce farklı alanlarda ağırlıklı olarak nitel (kalitatif) çalışmalar gerçekleştirilmiştir. Ancak konu ile ilgili nicel (kantitatif) çalışmaların sayısı yok denecek kadar azdır. Ayrıca nicel anlamda konuyla ilgili bir ölçek olmadığ sendromu ile ilgili bir ölçek geliştirilmesine ihtiyaç duyulmaktadır. Yapılan araştırmalar neticesinde, çalışmanın ilgili eksikliği gidermesi de amaçlanmaktadır. Turizm işletmelerinde ilgili sendrom bağlamında kadın yöneticilerin ve çalışanların hemcinslerini kendilerine yönelik bir sorun olarak görmeleri ve onlar üzerinde baskı ve ağırlık oluşturma arzuları çalışma ortamı, sunulan hizmet kalitesi ve işletme kültürü üzerinde olumsuz sonuçlara neden olabilmektedir. Ayrıca turizm alanında ve kadınların yoğun bir şekilde istihdam edildiği konaklama işletmelerinde bu eksikliği gidermek adına bu araştırmanın gerçekleştirilmesinin gerekli olduğuna karar verilmiştir. Kraliçe arı sendromu ile ilgili ölçek geliştirilmesiyle, kraliçe arı sendromunun konaklama işletmelerinde olup olmadığını belirlemek için anket tekniği uygulanmıştır. Geliştirilen ölçeğin hem literatüre katkı sağlaması hem de konaklama işletmelerinde uygulanması, araştırmanın önemine dikkat çekmektedir. 


\section{KRALIÇE ARI SENDROMU}

Kadınların eğitim ve iş hayatına katılım oranları gün geçtikçe artmaktadır. Ancak kadınlara biçilen toplumsal rol klişelerinden dolayı iş hayatında kadınlara yönelik meslek ayrımları yapılabilmektedir ve kadına uygun olan veya uygun olmayan iş alanları görüşü hâkim olabilmektedir. Aynı şekilde işletmelerde kadınların profesyonel ve yönetsel pozisyonlarda yer almaları konusunda da açık ve gizli engeller bulunabilmektedir. Kadınlara biçilen toplumsal rollere bağlı olarak, kadınların daha düşük sınıftaki görevlerde yer almaları uygun görülürken, liderlik ve yöneticilik gibi prestijin, tecrübenin ve gücün gerekli olduğu alanlarda yer almaları ve ilgili mertebelere yükselmeleri bir hayli zor olabilmektedir (Öztürk ve Cevher, 2015:162). Kadınların iş hayatında yükselmeleri konusunda bu ve benzeri çeşitli engeller bulunurken bazen de kadınların diğer kadınların yükselmeleri için koyduğu engeller söz konusu olmaktadır. Kadınların işletmelerindeki diğer kadınlara karşı takındıkları bu tutum ilgili literatürde kraliçe arı sendromu olarak tanımlanmaktadır (Bagilhole, 1993:442). Kraliçe arı sendromu "işletme içerisinde yönetici statüsünde olan kadınların diğer kadınları kendilerine rakip olarak görmesi ve onlara karşı katı ve yıldırıcı politikalar uygulaması" (Biernat ve Fuegen, 2001:719); "işletme içerisinde kadınların tıpkı bir erkek gibi başarıyı elde etmek veya elde ettikleri başarıyı korumak adına, diğer kadınlara karşı bireysel stratejiler geliştirerek statülerini korumak amacıyla sergiledikleri davranışların tamamı" (Ellemers vd., 2012:163-165); "kadınların üst düzey yönetici sıfatıyla içinde bulundukları gruplar içerisinde erkeksi bir yapıya sahip olarak, erkeklere karşı daha ılımlı ve yapıcı bir yönetim anlayışı benimserken diğer kadınları kendilerine ve makamlarnna karşı birer tehlike unsuru olarak görüp, onları grup içerisinden uzaklaştırmak ve orta dereceli yönetim kademelerine gelmelerini engellemek amacıyla bilinçli olarak takındıkları tavırların tamamı" şeklinde tanımlanmaktadır (Ezell vd., 1981:295).

Kraliçe arı sendromu ile sergilenen davranışların arkasında; yönetici olan kadınların kendilerine bağlı olarak işletmede görev alan diğer kadınlara örnek olmaktan ziyade, o mertebeye gelene kadar işletmedeki erkek çalışanların veya yöneticilerin davranışlarını benimseyerek, onlara benzemesi ile erkeksi davranışlar sergileme eğilimine sahip olmaları yatmaktadır. Ayrıca kadın çalışanların kadın yöneticilerinden beklentilerinin ve isteklerinin giderilmemesi ve kadın yöneticilerle kadın çalışanlar arasında iletişimin ve etkileşimin niteliksiz olması da bu duruma sebebiyet verebilmektedir (Akdöl ve Menteş, 2017:869). Kadın çalışanlar arasında hiyerarşinin dikey yönlü olmasıyla birlikte yeni kurulmakta olan ast-üst ilişkilerinde de sorunlar oluşabilmektedir. Esasında işletmelerde aynı sıfat ve seviyede bulunan kadınların ortak hareket etmeleri beklenmektedir. Fakat kadının yöneticilik mertebesine erişmesiyle bu beklenti sekteye uğrayabilmektedir. Kadınların kadın yöneticileri ile ilgili hissettikleri çekememezlik, özenme ve kıskançlık gibi duygular ve durumlar ast-üst ilişkisi içerisinde iletişimi tamamen engelleyebilmekte ya da daha önceden olumlu olan ilişkinin ve iletişimin sağlıklı olarak sürdürülmesine engel olabilmektedir (Baykal, 2018:162).

\section{İlgili Araştırmalar}

Ellemers vd., (2004) kadınların akademik kariyerlerinde kraliçe arı sendromuna maruz kalıp kalmadıklarını belirlemek amacıyla 312 katılımcı ile gerçekleştirdikleri araştırmalarının sonucunda kadın öğrencilerin ve kadın üniversite çalışanlarının, erkek öğrencilere ve erkek üniversite çalışanlara göre daha az bağlılık düzeyine sahip oldukları tespit edilmiştir. Camussi ve Leccardi (2005) görüşme tekniğinden yararlandıkları çalışmalarında, kadınlarda cinsiyet kalıplarını ve kadınların ağırlıklı olarak kendilerine biçilen kalıplara uyum gösterme eğilimine sahip olup olmadıklarını incelemişlerdir. Araştırma sonucunda kadınların iş ortamında cinsiyet farklılıklarını kabul etme eğilimine sahip olmalarına rağmen, cinsiyet arası ayrımcllığa bağlı 
olarak, erkekler ve kadınlar arasında güç dengesizliklerinin iş ortamında gözlemlenebildiği ve kadınların kademeleri arttıkça erkeksi tavırlar sergileme eğilimi gösterdikleri anlaşılmıştır. Mavin (2006) kraliçe arı davranışlarının nedenleri üzerine bir inceleme gerçekleştirmiştir. Araştırma sonucunda kadınlar arasında yaşanan gerginliğin gelecekte bu duruma maruz kalan kadınlarda da benzer davranışlara neden olabileceği belirlenmiştir.

Blau ve DeVaro (2007) işletmelerde kraliçe arı sendromunu inceledikleri çalışmalarında, kadınların erkeklere göre işlerinden daha az tatmin oldukları, terfi ve övgü beklenti düzeylerinin daha yüksek olduğu sonucuna ulaşmıştır. Ayrıca kadınların ilgili tutumu sergilemelerinde erkeksi işletme yapısının etkili olduğu sonucunu da ulaşmışlardır. Örücü vd., (2007) 200 katılımcı ile gerçekleştirdikleri çalışmada, işletmelerde kadınların liderlik ve yöneticilik konusunda yeterli görülmediği, kadınların aile ile ilgili sorumluluklarının daha fazla olduğunun düşünüldüğü ve işletmelerde kadınların birbirlerini çekemediklerini tespit etmiştir. Mavin (2008) kraliçe arı sendromu ile ilgili kavramsal bir araştırma gerçekleştirmiştir. Araştırmada kadınlarla ilişkilendirilen kraliçe arı; kadınların yönetimde yer almalarına engel teşkil edeceği, kadınların bu durumu yenmeleri için dayanışma içerisinde olmaları gerektiği ve üst yönetimde kadınların yer almaları için kadınların birbirlerini desteklemesi gerektiği ifade edilmektedir. Tanyeli (2008) işletme kültürü içinde cinsiyet ayrımcılı̆̆ı algılamasının kadın kariyeri üzerine etkilerini değerlendirdiği çalışmanın sonucunda kraliçe arı sendromunun kadınların kariyer engellerinden biri olduğu ifade edilmiştir. Baumgartner ve Schneider'in (2010) cam tavan sendromunun etkilerini belirlemek amacıyla alanında yetkin katılımcılarla gerçekleştirdikleri araştırma sonucunda, cam tavan sendromunun kadınların erkeksi davranışlar sergilemelerine, liderlik tarzlarında olumsuz etkilere ve kraliçe arı sendromuna yakalanarak astları kadınlara karşı baskı uygulamalarına neden olduğu belirlenmiştir.

Derks vd., (2011a) erkeksi yapıdaki işletmelerdeki kadın yöneticilerin kariyerlerini korumak adına erkeksi davranışlar sergiledikleri ve bu tarz eylemleri gerçekleştirirken ailelerini ve çocuklarını düşündüklerini belirtmişlerdir. Araştırmacılar ayrıca toplum tarafından biçilen sosyal kimlik ile de yakından ilişkili olduğu sonucuna ulaşılmıştır. Mavin ve Grandy'in (2012) çalışmasında; yöneticiliğin cinsiyete göre belirlenmemesi ile kadınsı ve erkeksi özelliklere eşit mesafede olunması gerektiği görüşünü savunmuştur. Virick ve Greer (2012) araştırmasına göre, yönetim kademesinde cinsiyet çeşitliliğinin olması gerekmektedir. İlgili durum ile rekabet avantajı sağlanacağı, işletmelerde kadın yöneticilerin bulunmasının önemli olduğu ve işletme kültürünün de ifade edilen yapıya uyumlu hale dönüştürülmesiyle başarının sağlanabileceği sonucuna ulaşmıştır. Karakuş (2014) kadınların kraliçe arı sendromuna maruz kaldıklarında kadınlık, hamilelik ve annelik gibi çeşitli rollere başvurabildikleri sonucuna ulaşmıştır. Cevher ve Öztürk (2015) çalışmasında; kadınların, kadınlara yönelik gerçekleştirdikleri mobbing davranışlarının nedenleri arasında kraliçe arı sendromunun etkili olduğu sonucuna ulaşılmıştır. Derks vd., (2015) işletme içerisinde azınlık düzeyinde bulunan Hindistanlı kadın çalışanların kraliçe arı sendromuna maruz kaldıkları sonucuna ulaşmıştır. Akman İmamoğlu ve Akman (2016) kadın öğretmenlerin kadın yöneticilerle çalışma hususunda güçlükler yaşadığı, kadın yöneticilerin alanında yetersiz oldukları, otorite kurmada etkili olamadıkları ve yöneticilerin böyle davranmalarında kraliçe arı sendromunun etkili olabileceği sonuçlarına ulaşmıştır.

Derks vd., (2016) kraliçe arı sendromunun yaşanmasında; erkek egemen yapıda çalışan ve yönetici kademesine ulaşan kadınların kurum kültürüne kendilerini adapte etmeleri ve kadınların yönetici oldukları grup içerisindeki diğer kadınlara kendilerini kabul ettirme isteğinin öne çıktığını belirtmektedir. Akdöl ve Menteş'in çalışmasında (2017) yönetici cinsiyetinin etkileme, katkı sağlamaya istekli olma ve sadakat ile bağlı olma boyutları üzerinde bir etkisinin 
olmadığı ve cinsiyetin hem kadın hem de erkek yönetici ile etkileşim açısından anlamlı bir farklılık sağlamadığını tespit etmiştir. Karatepe ve Arıbaş (2017) kadınların cinsiyet ayrımcılığı yaşamalarında kraliçe arı sendromunun da etkili olabildiği sonucuna varmıştır. Meriçelli'nin (2017) çalışmasında, kadınların yönetici olmamalarında cam tavan ve kraliçe arı sendromlarının etkili olduğu sonucuna ulaşmıştır. Baykal (2018) araştırmasında, kadın yöneticilerin erkekler tarafından yetersiz olarak görülmesi görüşüne bağlı olarak, diğer kadınlardan uzak durmayı seçtikleri, onlardan kaçtıkları ve onları desteklemediklerini belirtmiştir. Şengül vd., (2019) araştırmasında, kadın hemşirelerin duygusallık seviyelerinin daha yüksek olduğunu, erkek yöneticilere göre sorun çözmede bu anlamda daha başarılı olduklarını ve kadınların yönetimde daha başarılı oldukları sonucuna ulaşılmıştır.

Yukarıda özetlenen çalışmalardan elde edilen bilgilere göre, çeşitli sektörlerde kraliçe arı sendromunun incelendiği anlaşılmaktadır. Kadınların kraliçe arı sendromuna yakalanmalarında; toplumsal cinsiyet kalıplarını, kraliçe arı sendromunun örgütsel bağlılığı olumsuz etkilediği, kadın yöneticilerin kraliçe arı sendromuna yakalanmalarında çeşitli demografik özelliklerin etkili olduğu bilinmektedir. Kraliçe arı sendromunun ortaya çımasında cam tavan sendromu gibi çeşitli sendromların da etkili olduğu ve cinsiyetçi ve erkeksi örgüt kültürünün ilgili durumu tetiklediği tespit edilmiştir. Kraliçe arı sendromu gerçekleşmesiyle, kadın yöneticilerin astları kadınları bir tehdit olarak görmeleriyle astlarına mobbing yaptıkları, kadın yöneticilerin otorite kurmada yetersiz kalması gibi durumlar yaşanabilmektedir. Konuyla ilgili gerçekleştirilen çalışmalar ayrıca, kadınların yönetim kademesinde olmasıyla çeşitliliğin sağlanabileceği, kadın yöneticilerin duygusallık seviyelerinin yüksek olmasına bağlı olarak daha iyi yönetici olduklarını ifade etmektedir. Emek yoğun olan turizm sektöründe kraliçe arı sendromunun var olup olmadığının, varsa ifade edilen çalışmalardaki nedenlerle benzerlik gösterip göstermediğinin ortaya konulması ve konuya ilişkin ölçek geliştirilmesi araştırmanın temel amaçlarını oluşturmaktadır.

\section{YÖNTEM}

\section{Araştırmanın Amacı ve Modeli}

Yapılan bu çalışmanın temel amacın "Kraliçe Arı Sendromu" ile ilgili bir ölçek geliştirilmesi oluşturmaktadır. Konuyla ilgili geliştirilen ölçek ile Trakya Bölümü'nde faaliyetlerini sürdüren dört ve beş yıldızlı konaklama işletmelerinde çalışan kadınların (hâlihazırda ya da daha önce kadın yönetici emrinde çalışmış) işletmelerinde algıladıkları "Kraliçe Arı Sendromu" düzeylerinin ölçülmesi için uygulanmıştır. Kadın çalışanların demografik özellikleri (medeni durum, yaş, eğitim düzeyi, departman türü, işletmedeki pozisyon, işletmede çalışma süresi ve yöneticilik tecrübesi) ile "Kraliçe Arı Sendromu" boyutları arasındaki farklılıkların belirlenmesi de araştırmanın diğer amacını ve uygulama sahasını oluşturmaktadır.

Araştırmanın kapsamını oluşturan ve işletmelerde kadın çalışanların algıladıkları "Kraliçe Arı Sendromu" boyutlarını nicel yöntemlerle inceleyen ve ölçen çalışmaların sayısı literatürde yok denecek kadar azdır. İlgili literatürde konu ile ilgili ilk ampirik çalışmayı ve kavramın tanımını Staines vd., (1974) yapmıştır. Sonrasında ise çoğunluğu nitel yöntemlere dayanan çeşitli araştırmalar, Türk ve yabancı araştırmacılarca yürütülmüştür (Camussi ve Leccardi, 2005; Mavin, 2006; Blau ve DeVaro, 2007; Mavin, 2008; Baumgartner ve Schneider 2010; Mavin ve Grandy, 2012; Virick ve Greer, 2012; Kara vd., 2014; Karakuş, 2014; Cevher ve Öztürk, 2015; Derks vd., 2015; Er ve Adıgüzel, 2015; Öztürk ve Cevher, 2015; Akman İmamoğlu ve Akman, 2016; Derks vd., 2016; Karatepe ve Arıbaş, 2017; Baykal 2018; Şengül vd., 2019). 
Ulusal literatürde ilgili kavramı nitel yöntemlerle ölçen çalışmalar Akman İmamoğlu ve Akman (2016) ile sınırlıdır. İlgili araştırma kadın öğretmenlerle yürütülmüştür. İlgili literatürde konu ile ilgili olarak nicel yöntemlerin kullandığı ve turizm alanında gerçekleştirilmiş bir çalışmaya rastlanılmamıştır. Araştırma modeli ve ölçek ifadelerinin oluşturulması sürecinde, turizm işletmelerindeki kadın amirlere bağlı olarak görev alan kadın çalışanlarla yapılan görüşmelerle soru havuzu oluşturulmuştur. Kadınlardan alınan ifadeler kodlanmış ve tekrarlanma sıklıkları belirlenmiştir. Ayrıca ulusal ve uluslararası literatürdeki bazı nicel yöntemlerle gerçekleştirilmiş araştırmalardan (Cooper, 1997; Ellemers vd., 2004; Örücü vd., 2007; Tanyeli 2008; Derks vd., 2011a; Derks vd., 2011b; Akdöl ve Menteş, 2017) da yararlanılmıştır. İlgili nicel araştırmalardaki önermelerin ve boyutların bir kısmı, çalışma içerisinde gerekli geçerlik ve güvenirlik testlerine tabi tutulmuştur. Ancak bu çalışma, ilgili önermelerin ve boyutların kapsamlı olarak, analize tabi tutulduğu, alanındaki ilk çalışmalardan biridir.

Araştırmada, konaklama işletmelerinde kadın amire bağlı olarak çalışan kadın çalışanların "Kraliçe Arı Sendromu" algılarını belirlemek için bir ölçek geliştirme süreci yürütülmüştür. Aynı yöntem, mutfak öğrencilerinin yiyecek-içecek sektörüne yönelik algı ve tutumlarını belirlemeye yönelik bir ölçek geliştirme sürecinin yürütüldüğü Eren ve Aydın (2019) tarafından yapılan çalışma temelinde gerçekleştirilmiştir. Çalışmada çok boyutluluğu sağlayacak maddelere yer verilmiştir. Ölçeğin boyutları ile ilgili bilgi Şekil 1'de verilmektedir. Araştırmacıların ilgili çalışmaları çerçevesinde iki bölümden (demografik değişkenler ve araştırma önermeleri), üç boyuttan (destek boyutu, yapı boyutu ve yeterlilik boyutu) ve 35 önermeden oluşan (5'li Likert: Tamamen Katılıyorum (5)-Tamamen Katılmıyorum (1) aralığında) "Kraliçe Arı Sendromu" ölçeği oluşturulmuştur. Araştırma ölçeğinde katılımcıların demografik özelliklerinin belirlenmesine yönelik çoktan seçmeli cevapları olan 13 değişkene yer verilmiştir. Bunlar kadın çalışanların; medeni durumu, yaş aralığı, eğitim düzeyi, departman türü, işletmedeki pozisyonları, işletmede çalışma süreleri, genel çalışma süreleri, yöneticilik tecrübeleri, kadınların yönetici olmasına ilişkin bakış açları, işletmede yönetici olarak başarılı buldukları cinsiyet türü, işletmede çalışmayı daha kolay buldukları yönetici cinsiyet türü, işletmedeki kadın yöneticilerin kadın çalışanlara karşı tutumunu ve işletmede birden fazla kadın yönetici olmasını ilişkin bakış açıları ile ilgilidir.

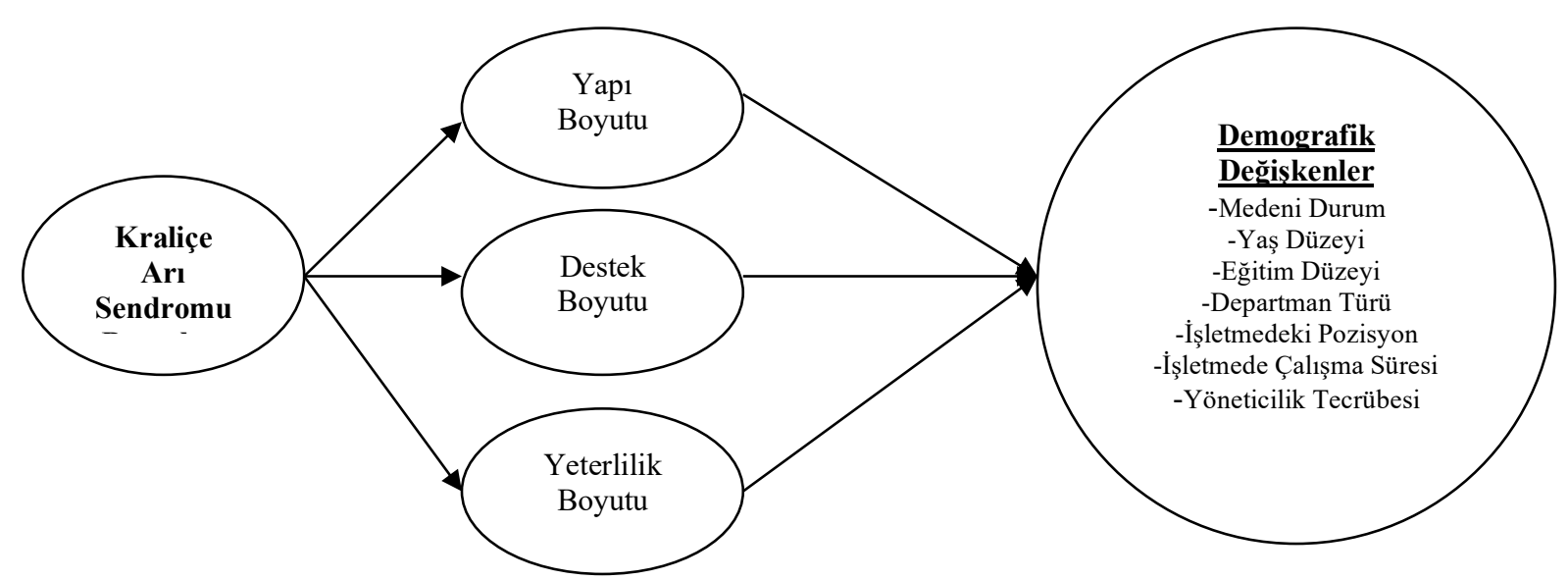

Şekil 1. Konaklama İşletmelerinin Kadın Çalışanlarının "Kraliçe Arı Sendromu" Algılarının Ölçülmesine İlişkin Araştırma Modeli. 
Çalışmada, ölçeğin içerik geçerliğinin sağlanması için konusunda uzman on akademisyene ve özel sektörde çalışmakta olan on insan kaynakları yöneticisine ölçek formu incelettirilmiştir. Akademisyenlerden ve insan kaynakları yöneticilerinden gelen içerik ve yazımsal öneriler kapsamında, gerekli revize işlemleri yapılmıştır. İlgili kişilerden ölçeğe ilişkin alınan son onaydan sonra, veri toplama süreci başlatılmıştır. Yapısal geçerlik konusunda ise içerik geçerliği, Alpha katsayısı, açıklayıcı ve doğrulayıcı faktör analizleri, birleşme, ayrılma ve tek boyutluluk gibi kıstasların yerine getirilmesi gerekmektedir. İçerik geçerliği sonucunda elde edilen geri bildirimler ve 34 kadın çalışandan elde edilen pilot verilerin (Alpha Katsayısı ,956) sonuçları çerçevesinde ölçeğe son hali verilerek, kadın yöneticilere bağlı istihdam edilen kadın çalışanlara uygulanmıştır.

\section{Araştırma Hipotezleri}

İlgili literatür ve ortaya konan araştırma modelinden hareketle aşağıdaki araştırma hipotezlerin test edilmesinin konunun anlaşılmasına katkı sağlayacağı düşünülmektedir.

- Hipotez 1: Kadın çalışanların medeni durum değişkeni ile "Kraliçe Arı Sendromu" boyutlarını değerlendirmeleri anlamlı farklılıklar (Derks vd., 2011b; Öztürk ve Cevher, 2015; İmamoğlu Akman ve Akman, 2016; Şengül vd., 2019) göstermektedir.

- Hipotez 2: Kadın çalışanların yaş düzeyi değişkeni ile "Kraliçe Arı Sendromu" boyutlarını değerlendirmeleri anlamlı farklılıklar (Ellermers vd., 2004) göstermektedir.

- Hipotez 3: Kadın çalışanların eğitim düzeyi değişkeni ile "Kraliçe Arı Sendromu" boyutlarını değerlendirmeleri anlamlı farklılıklar Akman İmamoğlu ve Akman, (2016) göstermektedir.

- Hipotez 4: Kadın çalışanların departman türü değişkeni ile "Kraliçe Arı Sendromu" boyutlarını değerlendirmeleri anlamlı farklılıklar (Virick ve Greer, 2012) göstermektedir.

- Hipotez 5: Kadın çalışanların işletmedeki pozisyon değişkeni ile "Kraliçe Arı Sendromu" boyutlarını değerlendirmeleri anlamlı farklılıklar (Derks vd., 2011a; Şengül vd., 2019) göstermektedir.

- Hipotez 6: Kadın çalışanların işletmede çalışma süresi değişkeni ile "Kraliçe Arı Sendromu" boyutlarını değerlendirmeleri anlamlı farklılıklar (Cehver ve Öztürk, 2015; Öztürk ve Cevher, 2015) göstermektedir.

- Hipotez 7: Kadın çalışanların yöneticilik tecrübesi değişkeni ile "Kraliçe Arı Sendromu" boyutların değerlendirmeleri anlamlı farklılıklar (Cooper, 1997; Virick ve Greer, 2012; Derks vd., 2016) göstermektedir.

\section{Araştırmanın Evreni, Örneklemi ve Veri Toplama Süreci}

Araştırma evrenini, Marmara Bölgesi'nin Trakya Bölümü'nde konaklama işletmelerinde çalışan kadın çalışanların bütünü oluşturmaktadır. Araştırma için ilgili alanın (Trakya Bölümü) seçilmesinde Türkiye'nin önemli turizm destinasyonlarından biri olarak düşünülmesi, kapsadığ 1 iller açısından özellikle tarihi yerleri, kültürel özellikleri ve doğal güzellikleri görme amaçlı seyahat eden turistlere yönelik konaklama işletmelerinin ve bu işletmelerde kadın çalışanların sayıca çok olması gibi faktörler etkili olmuştur. Turizm işletmelerinin genelinde olduğu gibi konaklama işletmelerinde de çalışan devir hızı ve mevsimsel çalışan sayısı değişim oranı yüksek düzeydedir. Bu araştırmanın yürütüldüğü Ekim 2019 döneminde de ilgili alandaki konaklama işletmelerinde mevsimlik çalışanlar işten ayrılmış olup tüm sezon istihdam edilen çalışanlarla faaliyetler sürdürülmektedir. Bu nedenle, araştırmanın veri toplama sürecinde ulaşılabilen katılımcı sayısı 134 kadın çalışan ile sınırlı kalmıştır. Araştırma sahasında evreni oluşturan 
toplam sayıya ilişkin resmi bir veriye ulaşılamamıştır. Bu nedenle, araştırmada kullanılan örneklem sayısının, sağlıklı test sonuçları vermesi ve örneklemin kendine has özelliklerinden (kadın yönetici amirliğinde çalışan kadın kişiler vb.) dolayı yeterli olduğu kanaatine varılmıştır. Araştırma katılımclarının belirlenmesi sürecinde özellikle konunun kendine has durumundan dolayı olasılığa dayalı olmayan örnekleme yöntemlerinden kasti (kararsal-amaçlı) örnekleme yönteminden yararlanılmıştır. Bu örnekleme yönteminde örnekleme rastgele seçilmez ve araştırmacı araştırma problemine cevap bulacağına inandığı kişileri kendisi seçer, yani ölçüt araştırmacının kendi yargısıdır (Yazıcıŏ̆lu ve Erdoğan, 2007:66; Altunışık vd., 2007:132).

Araştırma sonucunda anket formlarından elde edilen veriler SPSS istatistikî veri programında analize tabi tutulmuştur. Araştırma anketinden elde edilen kadın çalışanların demografik değişkenlerine ve araştırma önermelerine ilişkin veriler yüzde ve frekans değerleriyle analiz edilmiştir. Frekans analizinden sonra ölçeğin güvenirliği Alpha yöntemi ile analiz edilmiştir. Ölçekle ilgili diğer testlere geçilmeden önce ölçeğin normallik testi yapılmıştır. Bu çalışmada uygulanan normallik testi sonuçlarına göre çarpıklık (skewness) değeri-,364 ile ,236 arasında ve basıklık (kurtosis) değeri ise ,764 ile -,311 arasında değişmektedir. Tabachnick ve Fidell'e (2013) göre ilgili değerler -1.5 ile +1.5 olduğu için ölçek normal dağılıma sahiptir denilebilir. Normallik testinde verilerin Shapiro-Wilks değerlerinin anlamlılık düzeyinin $p>0,05$ olduğu tespit edilmiştir. Bu sonuç, ölçeğin parametrik testler ( $t$ test, ANOVA vb.) için uygun olduğunu göstermektedir. Güvenirlik ve normallik analizlerinden sonra kadın çalışanların "Kraliçe Arı Sendromu" değerlendirmelerine ilişkin ölçeğin yapı geçerliğini test etmek amacıyla açıklayıcı (keşfedici) faktör analizi yapılmıştır. Analiz kısmında son olarak belirlenen demografik değişkenler ve araştırma boyutları arasındaki farklılıkların belirlenmesi amacıyla fark testleri ( $\mathrm{t}$ test ve ANOVA) yapılmıştır. ANOVA testlerinde değişkenler ve boyutlar arasındaki farkların tespiti için dergi yazım kuralları göz önünde bulundurulup tabloları sadeleştirmek adına, anlamlı sonuçlar veren değişkenler ile boyutların tabloları daha detaylı verilmeye çalışılmış olup; AVOVA analizlerinde değişkenlerin anlamlılığını test etmek için Schfee ve Tamhane's analizlerinde gerekli durumlarda yararlanılmıştır. Tablolarda verilen $\mathrm{p}$ değerleri, değişkenler ve boyutların anlamlığını gösteren değerdir. İlgili Anova tablolarının oluşturulmasında, YÖK tez ve diğer bilimsel yayın mecralarında yaygın olarak kullanılan, görselleştirme ve yorumlama teknikleri izlenmiştir. İlgili tablolar ve analiz yorumlarının, araştırma okuyucularının anlama ve yorumlama düzeylerine hitap edecek sadelikte ve anlaşılırlıkta olduğu düşünülmektedir.

\section{BULGULAR}

Araştırmanın örnekleme özelliklerine ilişkin yapılan frekans analizi sonuçlarına göre; kadın çalışanların \%36,6'sı bekâr ve \%63,4'ü evlidir. Katılımcıların \%32,8'i 16-30 yaş aralığında ve $\% 67,2$ ' si 31-65 yaş aralığındadır. Katılımcıların \%6's ilköğretim, \%24,6'sı lise, \%25,1'i ön lisans ve $\% 34,3$ 'ü lisans düzeyinde eğitime sahiptir. Katılımcıların \%17,9'u ön büro, \%18,7'si kat hizmetleri, \%11,2'si servis, \%15,7'si mutfak, \%10,4'ü halkla ilişkiler, \%14,2'si insan kaynakları ve \%11,9'u misafirlerle ilişkiler departmanlarında çalışmaktadır. Katılımcıların \%42,5'i alt kademe çalışan, $\% 14,2$ 'si üst kademe çalışan, \%21,6'sı alt kademe yönetici, $\% 8,2$ 'si orta kademe yönetici ve $\% 13,4^{\prime}$ ü stajyer pozisyonundadır. Katılımcıların \%70,1'i 0-5 yıl arası ve \%29,9'u 6-10 yıl arası aynı işletmede çalışırlarken \%20,1'i 0-5 yıl arası, \%27,6'sı 6-10 yıl arası ve \%52,2'si 11-15 yıl arası toplam iş tecrübesine sahiptir. Katılımcıların \%37,3'ü yöneticilik tecrübesine sahipken \%62,7'si herhangi bir yöneticilik tecrübesine sahip değildir. Katılımcıların \%26,1'i kadınların yönetici olmasını olumlu değerlendirirken \%73,9'u olumsuz değerlendirmektedir. Katılımcıların \%88,8'i işletmelerinde erkekleri ve \%14,2'si kadınları yönetici olarak daha başarılı bulmaktadır. Katılımcıların \%81,3'ü işletmelerinde erkek yöneticilerle \%18,7'si ise kadın yöneticilerle çalışmayı 
daha kolay bulmaktadır. Katılımcıların \%70,1'i işletmelerde kadın yöneticilerin kadın çalışanları engellediğini $\% 29,9^{\prime} u$ ise engellemediğini düşünmektedir. Katılımcıların \%20,1'i işletmelerde birden fazla kadın yönetici olmasını desteklerken \%79,9'u bu öneriyi desteklememektedir.

Tablo 1. Kadın Çalışanların Demografik Değişken Dağılımı

\begin{tabular}{|c|c|c|c|}
\hline Demografik Özellikler & & (n) & $(\%)$ \\
\hline \multirow{2}{*}{ Medeni Durum } & Bekâr & 49 & 36,6 \\
\hline & Evli & 85 & 63,4 \\
\hline \multirow{2}{*}{ Yaş } & 16-30 Yaş Arası & 44 & 32,8 \\
\hline & 31-65 Yaş Arası & 90 & 67,2 \\
\hline \multirow{4}{*}{ Eğitim Düzeyi } & İlköğretim & 8 & 6,0 \\
\hline & Lise & 33 & 24,6 \\
\hline & Ön lisans & 47 & 25,1 \\
\hline & Lisans & 46 & 34,3 \\
\hline \multirow{7}{*}{ Departman } & Ön büro & 24 & 17,9 \\
\hline & Kat Hizmetleri & 25 & 18,7 \\
\hline & Servis & 15 & 11,2 \\
\hline & Mutfak & 21 & 15,7 \\
\hline & Halkla İlişkiler & 14 & 10,4 \\
\hline & İnsan Kaynakları & 19 & 14,2 \\
\hline & Misafirle İlişkiler & 16 & 11,9 \\
\hline \multirow{5}{*}{ Pozisyon } & Alt Kademe Çalışan & 58 & 42,5 \\
\hline & Üst Kademe Çalışan & 17 & 14,2 \\
\hline & Alt Kademe Yönetici & 30 & 21,6 \\
\hline & Orta Kademe Yönetici & 11 & 8,2 \\
\hline & Stajyer & 18 & 13,4 \\
\hline \multirow{2}{*}{ İşletmede Çalışma Süresi } & 0-5 Y1l Arasi & 94 & 70,1 \\
\hline & 6-10 Y1l Aras1 & 40 & 29,9 \\
\hline \multirow{3}{*}{ Genel Çalışma Süresi } & 0-5 Y1l Aras1 & 27 & 20,1 \\
\hline & 6-10 Y1l Aras1 & 37 & 27,6 \\
\hline & 11-15 Yil Arası & 70 & 52,2 \\
\hline \multirow{2}{*}{ Yöneticilik Tecrübesi } & Evet & 50 & 37,3 \\
\hline & Hayır & 84 & 62,7 \\
\hline \multirow{2}{*}{$\begin{array}{l}\text { Kadın Yöneticilere Bakış } \\
\text { Açısı }\end{array}$} & Olumlu & 35 & 26,1 \\
\hline & Olumsuz & 99 & 73,9 \\
\hline \multirow{2}{*}{$\begin{array}{l}\text { İşletme Yöneticilerini } \\
\text { Başarılı Bulma }\end{array}$} & Erkek Yönetici & 115 & 88,8 \\
\hline & Kadın Yönetici & 19 & 14,2 \\
\hline \multirow{2}{*}{$\begin{array}{l}\text { Çalışma Açısından Kolay } \\
\text { Yönetici Türü }\end{array}$} & Erkek Yönetici & 109 & 81,3 \\
\hline & Kadın Yönetici & 25 & 18,7 \\
\hline \multirow{2}{*}{$\begin{array}{l}\text { Kadın Yöneticilerin Kadın } \\
\text { Çalışanları Engellemesi }\end{array}$} & Evet & 94 & 70,1 \\
\hline & Hayır & 40 & 29,9 \\
\hline \multirow{2}{*}{$\begin{array}{l}\text { İşletmede Birden Fazla } \\
\text { Kadın Yöneticiye Destek } \\
\text { Düzeyi }\end{array}$} & Evet & 27 & 20,1 \\
\hline & Hayır & 107 & 79,9 \\
\hline & Toplam & 134 & 100 \\
\hline
\end{tabular}


Kadın çalışanların araştırma önermelerine ilişkin değerlendirmelerine yönelik yapılan analiz (Descriptive) sonuçlarına göre; kadın yöneticiler estetiktir ve çalışma ortamını güzelleştirir $(\tilde{\mathrm{x}}=4,54)$, kadın yöneticiler astlarını ezme eğilimine sahip olabilmektedir $(\tilde{\mathrm{x}}=4,49)$, kadın yöneticiler bazen bencil olabilmektedir $(\tilde{x}=4,50)$, kadın yöneticilerin çalışma ortamında iletişim becerileri yeterli olamaya bilmektedir $(\tilde{x}=4,50)$, kadın yöneticiler işle ilgili konuları kişiselleştirirler $(\tilde{x}=4,49)$, kadın yöneticilerin birden fazla olduğu bölümlerde güç çatışması olabilir ( $\tilde{x}=4,48)$, kadın yöneticilere işyerimde destek vermek istemem $(\tilde{x}=4,45)$, kadın yöneticiler, yöneticilik konusunda yeterli tecrübeye sahip değildir $(\tilde{x}=4,45)$, kadın yöneticilere bakış açım "kadın kadının kuyusunu kazar." noktasındadır $(\tilde{\mathrm{x}}=4,44)$, kadın yöneticiler ön yargılı olabilmektedir $(\tilde{\mathrm{x}}=4,43)$ ve kadın yöneticiler astları kadınların terfi almalarını ve yükselmelerini istememektedir $(\tilde{x}=4,41)$, önermelerini değerlendirmeleri yüksek düzeyde katılım göstermiştir.

Kadın çalışanların diğer önermelerini değerlendirme düzeyleri ise orta ve birbirine yakın düzeyde $(\tilde{x}=4,00-4,40)$ gerçekleşmiştir. Kadın yöneticiler çalışma ortamında otorite sağlayabilmektedir $(\tilde{\mathrm{x}}=3,97)$, kadın yöneticilere sorunlarımı daha rahat ifade ederim $(\tilde{\mathrm{x}}=3,91)$, kadın olarak, kadın yöneticiler işe gelmemde etkili olabilmektedir ( $\tilde{x}=3,85)$, kadın yöneticiler, duygusaldır $(\tilde{x}=3,87)$ ve kadın yöneticilerime fikir ve görüşümün olduğu konularda destek veririm $(\tilde{x}=3,73)$, önermelerine ise kadın çalışanların katılım düzeyleri düşük düzeyde gerçekleşmiştir.

Yapılan güvenirlik analizi sonucunda araştırmada kullanılan kadın çalışanların "Kraliçe Arı Sendromu" değerlendirmelerine ilişkin ölçeğin Alpha katsayısı ,941 olarak bulunmuştur. Elde edilen katsayı oranları ölçeğin güvenilir olduğuna işaret etmektedir (Ural ve Kılıç, 2005:258). Çalışmada yararlanılan açıklayıcı faktör analizi sonucunda; KMO değeri ,878 olarak $(\mathrm{p}=0,000$ anlamlılık düzeyinde) belirlenmiştir. Bu değer literatürde kabul görmüş değer aralıkları çerçevesinde mükemmel olarak değerlendirilmektedir (Durmuş, vd., 2010:79). Ayrıca Barlett's Test of Sphericity-Küresellik Testi sonucu 3462,620 olarak tespit edilmiştir. Bu oranın düzeyi de örnekleme büyüklügünün faktör analizi için yeterli ve uygun olduğunu göstermektedir. Açıklayıcı faktör analizinde oluşturulan matrislerin her bir elemanı her bir değişkenle her bir faktör arasındaki korelâsyonu gösteren faktör ağırlıklarıdır. Rotasyona tabi tutulmamış matrisin yorumlanması oldukça güçtür ve matrisin varimax rotasyonuna tabi tutulması gerekmektedir (İlban, 2008:133). Çalışmaya dâhil edilen 134 örnekleme dikkate alındığında 0,05 anlamlılık düzeyinde bir sonuca ulaşmak için faktör yüklerini incelemek gerekmektedir. Bir değişkenin $0,3^{\prime}$ lük faktör yükü faktör tarafından açılanan varyansın $\% 9$ olduğunu göstermektedir. Bu düzeydeki varyans ise önemlidir. Bir çalışmada faktör yüklerinin 0,30-0,59 olması orta düzey, 0,60 ve üzerinde gerçekleşmesi yüksek düzey büyüklükler olarak değerlendirilir (Büyüköztürk, 2002:473-474). Çalışmada hem faktör yükleri açısından 0,30'un altında olan hem de eşkökenlilik (communalities) değerleri 0,50'nin altında olan önermeler değerlendirme dışı bırakılarak açıklayıcı faktör analizinin geçerliliğinin arttırılması amaçlanmıştır. Yapılan bu iki işlem sonucunda ölçekte yer alan 35 önermeden 8 'inin (Kadın yöneticiler, yakın oldukları kişilere karşı daha ılımlıdır, kadın yöneticilerde kıskançlık olabilmektedir, kadın yöneticiler duygusaldır, kadın yöneticiler ayrıntılara önem gösterirler, kadın yöneticilerin sorumluluk duyguları daha yüksektir, kadın yöneticiler bazen kindar olabilmektedir, kadın yöneticiler, genelde kadın astlarına karşı nazik değildir ve kadın yöneticiler astları kadınların terfi almalarını ve yükselmelerini istememektedir) ölçekten çıkarılmasına karar verilmiştir. Kalan 27 önerme ile ikinci kez uygulanan açıklayıcı faktör analizi sonucunda bu önermelerin 3 boyut altında toplandığı belirlenmiş ve ilgili boyutların "Kraliçe Arı Sendromu" değerlendirme ölçeği boyutları olarak Destek Boyutu (DB), Yapı Boyutu (YAB) ve Yeterlilik Boyutu (YEB) şeklinde adlandırılmalarına karar verilmiştir. 
Tablo 2. Kadın Çalışanların Araştırma Önermelerine İlişkin Değerlendirmeleri

\begin{tabular}{|c|c|c|}
\hline Araştırma Önermeleri & $\begin{array}{l}\text { Ort. } \\
(\tilde{x})\end{array}$ & $\begin{array}{c}\text { S. } \\
\text { Sapma }\end{array}$ \\
\hline Kadın yöneticilere sorunlarımı daha rahat ifade ederim. & 3,91 & 1,28 \\
\hline Kadın yöneticiler empati sahibidir ve sorunlarımı anlar. & 4,20 & 1,19 \\
\hline Kadın yöneticiler, yakın oldukları kişilere karşı daha ılımlıdır. & 4,05 & 1,14 \\
\hline Kadın olarak, kadın yöneticiler işe gelmemde etkili olabilmektedir. & 3,85 & 1,19 \\
\hline $\begin{array}{l}\text { Kadın yöneticilerime, fikir ve görüşümün olduğu konularda destek } \\
\text { veririm. }\end{array}$ & 3,73 & 1,15 \\
\hline Kadın yöneticilerin birden fazla olduğu bölümlerde yarış ortamı olabilir. & 4,06 & 1,30 \\
\hline Kadın yöneticilerin birden fazla olduğu bölümlerde güç çatışması olabilir. & 4,48 & 1,00 \\
\hline Kadın yöneticiler astları kadınlara destek vermede isteksiz olabilmektedir. & 4,04 & 1,10 \\
\hline Kadın yöneticilere işyerimde destek vermek istemem. & 4,45 & 1,08 \\
\hline $\begin{array}{l}\text { Kadın yöneticilere bakış açım "kadın kadının kuyusunu kazar." } \\
\text { noktasındadır. }\end{array}$ & 4,44 & 1,04 \\
\hline Kadın yöneticiler ayrıntılara önem gösterir. & 4,17 & 1,13 \\
\hline Kadın yöneticilerin sorumluluk duyguları daha yüksektir. & 4,29 & 1,11 \\
\hline Kadın yöneticiler estetiktir ve çalışma ortamını güzelleştirir. & 4,54 & ,99 \\
\hline Kadın yöneticiler düşüncelerini açıkça dile getirir. & 4,26 & 1,25 \\
\hline Kadın yöneticiler duygusaldır. & 3,87 & 1,25 \\
\hline Kadın yöneticiler dedikodu yapmamaktadır. & 4,02 & 1,21 \\
\hline Kadın yöneticiler, genelde kadın astlarına karşı nazik değildir. & 4,38 & 1,10 \\
\hline Kadın yöneticilerde kıskançlık olabilmektedir. & 4,14 & 1,19 \\
\hline Kadın yöneticiler bazen kindar olabilmektedir. & 4,20 & 1,13 \\
\hline Kadın yöneticiler bazen bencil olabilmektedir. & 4,50 & 86 \\
\hline Kadın yöneticiler önyargılı olabilmektedir. & 4,43 & ,92 \\
\hline Kadın yöneticiler astlarına karşı asılsız suçlamalarda bulunabilir. & 4,26 & 1,06 \\
\hline Kadın yöneticiler işle ilgili konuları kişiselleştirebilirler. & 4,49 & ,95 \\
\hline Kadın yöneticiler astlarına karşı kırıcı davranışlar sergileyebilmektedir. & 4,00 & 1,10 \\
\hline Kadın yöneticiler, astlarını ezme eğilimine sahip olabilmektedir. & 4,49 & 1,07 \\
\hline Kadın yöneticiler erkek yönetici gibi davranışlar sergileyebilmektedir. & 4,15 & 1,04 \\
\hline $\begin{array}{l}\text { Kadın yöneticiler, astları kadınların terfi almalarını ve yükselmelerini } \\
\text { istememektedir. }\end{array}$ & 4,41 & ,94 \\
\hline Kadın yöneticiler çalışma ortamında otorite sağlayabilmektedir. & 3,97 & 1,17 \\
\hline $\begin{array}{l}\text { Kadın yöneticiler çalışma ortamında yaşanan sorunları çözmede } \\
\text { yeterlidir. }\end{array}$ & 4,18 & 1,18 \\
\hline $\begin{array}{l}\text { Kadın yöneticilerin çalışma ortamındaki iletişim becerileri yeterli olamaya } \\
\text { bilmektedir. }\end{array}$ & 4,50 & 94 \\
\hline Kadın yöneticiler, yöneticilik konusunda yeterli tecrübeye sahip değildir. & 4,45 & 81 \\
\hline Kadın yöneticilerde duygularını mantıklarının önünde tutabilmektedir. & 4,39 & 86 \\
\hline Kadın yöneticiler planlı ve programlı değildir. & 4,39 & ,97 \\
\hline Kadın yöneticiler işlerinin ehilleri değildir. & 4,22 & 1,06 \\
\hline $\begin{array}{l}\text { Kadın yöneticiler erkek yöneticilerle aynı yeterlilik düzeyine } \\
\text { ulaşamamaktadır. }\end{array}$ & 4,34 & ,92 \\
\hline
\end{tabular}

Destek boyutu (DB); kadın yöneticilerin birden fazla olduğu bölümlerde güç çatışması olabilir, kadın yöneticilerin birden fazla olduğu bölümlerde yarış ortamı olabilir, kadın yöneticilere 
sorunlarımı daha rahat ifade ederim, kadın yöneticiler empati sahibidir ve sorunlarımı anlar, kadın yöneticilere işyerimde destek vermek istemem, kadın yöneticiler astları kadınlara destek vermede isteksiz olabilmektedir, kadın yöneticilere bakış açım "Kadın kadının kuyusunu kazar." noktasına yakındır, kadın olarak, kadın yöneticiler işe gelmemde etkili olabilmektedir ve kadın yöneticilerime, fikir ve görüşümün olduğu konularda destek veririm önermelerinden oluşmaktadır. Boyut toplam varyansın \%19,731'ini açıklamaktadır ve boyutun güvenirlik katsayısı ,916 olarak gerçekleşmiştir. Boyutta kadın olarak, kadın yöneticiler işe gelmemde etkili olabilmektedir (,772) önermesi en fazla faktör yüküne sahip önerme ve kadın yöneticiler astları kadınlara destek vermede isteksiz olabilmektedir $(, 593)$ en az faktör yüküne sahip önerme olmuştur.

Yapı boyutu (YAB); kadın yöneticiler bazen bencil olabilmektedir, kadın yöneticiler önyargılı olabilmektedir, kadın yöneticiler kadın astlarına karşı asılsız suçlamalarda bulunabilir, kadın yöneticiler dedikodu yapmamaktadır, kadın yöneticiler işle ilgili konuları kişiselleştirir, kadın yöneticiler astlarını ezme eğilimine sahip olabilmektedir, kadın yöneticiler düşüncelerini açıç̧a dile getirirler ve kadın yöneticiler estetiktir ve çalışma ortamını güzelleştirir önermelerinden oluşmaktadır. Boyut toplam varyansın \%20,001'ini açıklamaktadır ve boyutun güvenirlik katsayısı ,911 olarak gerçekleşmiştir. Boyutta kadın yöneticiler estetiktir ve çalışma ortamını güzelleştirir $($,845) önermesi en fazla faktör yüküne sahip önerme ve kadın yöneticiler dedikodu yapmamaktadır $(, 632)$ en az faktör yüküne sahip önerme olmuştur.

Yeterlilik boyutu (YEB); kadın yöneticiler kadın astlarına karşı kırıcı davranışlar sergileyebilmektedir, kadın yöneticiler erkek yönetici gibi davranışlar sergileyebilmektedir, kadın yöneticiler yöneticilik konusunda yeterli tecrübeye sahip değildir, kadın yöneticilerde duygularını mantıklarının önünde tutabilmektedir, kadın yöneticiler çalışma ortamında otorite sağlayabilmektedir, kadın yöneticiler erkek yöneticilerle aynı yeterlilik düzeyine ulaşamaz, kadın yöneticiler işlerinin ehilleri değildir, kadın yöneticiler planlı ve programlı değildir, kadın yöneticiler çalışma ortamında yaşanan sorunları çözmede yeterlidir ve kadın yöneticilerin çalışma ortamındaki iletişim becerileri yeterli olamaya bilmektedir önermelerinden oluşmaktadır. Boyut toplam varyansın \%18,960'ını açılamaktadır ve boyutun güvenirlik katsayısı ,898 olarak gerçekleşmiştir. Boyutta kadın yöneticiler işlerinin ehilleri değildir $(, 803)$ önermesi en fazla faktör yüküne sahip önerme ve kadın yöneticiler kadın astlarına karşı kırıcı davranışlar sergileyebilmektedir $(, 564)$ en az faktör yüküne sahip önerme olmuştur.

Kadın çalışanların medeni durum değişkeni (t test); YAB $(, 028)$ ve DB $(, 048)$ ile kadın çalışanların medeni durum değişkeni arasında anlamlı farklılıklar tespit edilmiştir. YAB boyutunu evli kadın çalışanların $(\tilde{x}=4,41)$ bekâr kadın çalışanlara göre $(\tilde{x}=4,30)$ yine Destek boyutunu evli kadın çalışanların $(\tilde{x}=4,17)$ bekâr kadın çalışanlara göre $(\tilde{x}=4,05)$ daha yüksek düzeyde değerlendirdikleri belirlenmiştir.

Kadın çalışanların yaş değişkeni (t test); YAB $(, 017)$ ve DB $(, 049)$ ile kadın çalışanların yaş değişkeni arasında anlamlı farklılıklar tespit edilmiştir. Yapı boyutunu 16-30 yaş aralığındaki kadın çalışanların $(\tilde{x}=4,51) 31-65$ yaş aralığındaki kadın çalışanlara göre $(\tilde{x}=4,30)$ yine DB boyutunu 1630 yaş aralığındaki kadın çalışanların $(\tilde{x}=4,29)$ 31-65 yaş aralığındaki kadın çalışanlara göre $(\tilde{\mathrm{X}}=4,05)$ daha yüksek düzeyde değerlendirdikleri belirlenmiştir. 
Tablo 3. Araştırma Ölçeğinin Faktör Analizi Sonuçları (n=134)

\begin{tabular}{|c|c|c|c|}
\hline Araştırma Önermeleri & (DB) & (YAB) & (YEB) \\
\hline Kadın olarak, kadın yöneticiler işe gelmemde etkili olabilmektedir. & 772 & & \\
\hline Kadın yöneticilere işyerimde destek vermek istemem. & ,751 & & \\
\hline $\begin{array}{l}\text { Kadın yöneticilere bakış açım "kadın kadının kuyusunu kazar." } \\
\text { noktasındadır. }\end{array}$ & ,749 & & \\
\hline Kadın yöneticilerime, fikir ve görüşümün olduğu konularda destek veririm. & ,739 & & \\
\hline Kadın yöneticiler empati sahibidir ve sorunlarımı anlar. & ,729 & & \\
\hline Kadın yöneticilerin birden fazla olduğu bölümlerde yarış ortamı olabilir. & ,676 & & \\
\hline $\begin{array}{l}\text { Kadın yöneticilerin birden fazla olduğu bölümlerde güç çatışması } \\
\text { yaşanabilir. }\end{array}$ & ,648 & & \\
\hline Kadın yöneticilere sorunlarımı daha rahat ifade ederim. & 619 & & \\
\hline Kadın yöneticiler astları kadınlara destek vermede isteksiz olabilmektedir & ,593 & & \\
\hline Kadın yöneticiler estetiktir ve çalışma ortamını güzelleştirir. & & 845 & \\
\hline Kadın yöneticiler önyargılı olabilmektedir. & & 793 & \\
\hline Kadın yöneticiler astlarını ezme eğilimine sahip olabilmektedir. & & 763 & \\
\hline Kadın yöneticiler bazen bencil olabilmektedir. & & ,742 & \\
\hline Kadın yöneticiler kadın astlarına karşı asılsız suçlamalarda bulunabilir. & & ,707 & \\
\hline Kadın yöneticiler düşüncelerini açıkça dile getirir. & & 693 & \\
\hline Kadın yöneticiler işle ilgili konuları kişiselleştirir. & & ,644 & \\
\hline Kadın yöneticiler dedikodu yapmamaktadır. & & 632 & \\
\hline Kadın yöneticiler işlerinin ehilleri değildir. & & & 803 \\
\hline Kadın yöneticiler erkek yönetici gibi davranışlar sergileyebilmektedir. & & & 779 \\
\hline Kadın yöneticiler planlı ve programlı değildir. & & & ,763 \\
\hline Kadın yöneticiler çalışma ortamında otorite sağlayabilmektedir. & & & ,723 \\
\hline Kadın yöneticilerde duygularını mantıklarının önünde tutabilmektedir. & & & 713 \\
\hline $\begin{array}{l}\text { Kadın yöneticiler erkek yöneticilerle aynı yeterlilik düzeyine } \\
\text { ulaşamamaktadır. }\end{array}$ & & & ,700 \\
\hline Kadın yöneticiler çalışma ortamında yaşanan sorunları çözmede yeterlidir. & & & 697 \\
\hline $\begin{array}{l}\text { Kadın yöneticilerin çalışma ortamındaki iletişim becerileri yeterli olamaya } \\
\text { bilmektedir. }\end{array}$ & & & 641 \\
\hline Kadın yöneticiler, yöneticilik konusunda yeterli tecrübeye sahip değildir. & & & ,603 \\
\hline Kadın yöneticiler kadın astlarına karşı kırıcı davranışlar sergileyebilmektedir. & & & ,564 \\
\hline Faktörlere Ait Cronbach Alpha Değerleri & ,916 &, 911 & ,898 \\
\hline Faktörlere Ait Açılanan Varyans Değerleri (\%) & $\begin{array}{c}19,7 \\
31\end{array}$ & 20,001 & $\begin{array}{c}18,96 \\
0\end{array}$ \\
\hline Toplam Açıklanan Varyans (\%) & \multicolumn{3}{|c|}{58,422} \\
\hline KMO Örnekleme Ölçüm Yeterliliği & \multicolumn{3}{|c|}{878} \\
\hline Barlett Küresel Test Değeri & \multicolumn{3}{|c|}{3462,620} \\
\hline Sig. $p$ değeri-Olasılık Değeri & \multicolumn{3}{|c|}{, 000} \\
\hline
\end{tabular}


Tablo 4. Medeni Durum T Test Sonuçları

\begin{tabular}{|l|l|c|c|c|c|c|}
\hline \multicolumn{2}{|c|}{} & \multicolumn{2}{c|}{$\begin{array}{c}\text { Var. Eşitliği } \\
\text { Testi }\end{array}$} & \multicolumn{2}{|c|}{} \\
\hline Faktör & Gruplar & $\tilde{\mathbf{x}}$ & Levene & $\mathbf{p}$ & $\mathbf{t}$ & $\mathbf{P}$ \\
\hline \multirow{2}{*}{ YAB } & Evli & 4,41 & \multirow{2}{*}{, 679} & \multirow{2}{*}{, 172} & 2,795 & \multirow{2}{*}{, 028} \\
\cline { 2 - 5 } & Bekâr & 4,30 & \multirow{2}{*}{, 878} & \multirow{2}{*}{, 024} & 2,762 & \multirow{2}{*}{, 048} \\
\hline \multirow{2}{*}{ DB } & Evli & 4,17 & 4,05 & & &
\end{tabular}

Tablo 5. Yaş Değişkeni T Test Sonuçları

\begin{tabular}{|c|c|c|c|c|c|c|}
\hline \multirow[b]{2}{*}{ Faktör } & \multirow[b]{2}{*}{ Gruplar } & \multirow[b]{2}{*}{$\tilde{\mathbf{x}}$} & \multicolumn{2}{|c|}{$\begin{array}{c}\text { Var. Eşitliği } \\
\text { Testi }\end{array}$} & \multirow[b]{2}{*}{$t$} & \multirow[b]{2}{*}{$\mathbf{P}$} \\
\hline & & & Levene & $p$ & & \\
\hline \multirow{2}{*}{ YAB } & 16-30 Yaş & 4,51 & \multirow{2}{*}{3,712} & \multirow{2}{*}{,056 } & \multirow{2}{*}{2,358} & \multirow{2}{*}{,017 } \\
\hline & 31-65 Yaş & 4,30 & & & & \\
\hline \multirow{2}{*}{ DB } & 16-30 Yaş & 4,29 & \multirow{2}{*}{,925 } & \multirow{2}{*}{,338 } & \multirow{2}{*}{2,418} & \multirow{2}{*}{,049 } \\
\hline & 31-65 Yaş & 4,05 & & & & \\
\hline
\end{tabular}

Kadın çalışanların aynı işletmede çalışma süresi değişkeni ( $t$ test); araştırma boyutlarından sadece YEB $(, 016)$ ile kadın çalışanların aynı işletmede çalışma süresi değişkeni arasında anlamlı farklılıklar tespit edilmiştir. YEB, 0-5 yıldır aynı işletmede çalışan kadınların ( $\tilde{x}=4,36)$ 6-10 yıldır aynı işletmede çalışan kadınlara göre $(\tilde{\mathrm{x}}=4,03)$ daha yüksek düzeyde değerlendirdikleri belirlenmiştir.

Tablo 6. Aynı İşletmede Çalışma Süresi Değişkeni T Test Sonuçları

\begin{tabular}{|c|c|c|c|c|c|c|}
\hline & & & $\begin{array}{r}\text { Var. } \mathrm{E} \\
\mathrm{Te} \\
\end{array}$ & $\begin{array}{l}\text { tliği } \\
\text { i }\end{array}$ & & \\
\hline Faktör & Gruplar & $\tilde{\mathbf{x}}$ & Levene & $\mathbf{p}$ & $\mathbf{t}$ & $\mathbf{P}$ \\
\hline \multirow{2}{*}{ YEB } & $0-5 Y_{11}$ & 4,36 & \multirow{2}{*}{1,279} & \multirow{2}{*}{ 260 } & \multirow{2}{*}{2,448} & \multirow{2}{*}{ 016 } \\
\hline & 6-10 Y Y & 4,03 & & & & \\
\hline
\end{tabular}

Kadın çalışanların yöneticilik tecrübesi değiş̧keni ( $t$ test); araştırma boyutlarından sadece YEB $(, 041)$ ile kadın çalışanların yöneticilik tecrübesine sahip olma değişkeni arasında anlamlı farklılıklar tespit edilmiştir. Yeterlilik boyutunu yöneticilik tecrübesine sahip olmayan kadın çalışanların $(\tilde{x}=4,29)$ yöneticilik tecrübesine sahip kadın çalışanlara göre $(\tilde{x}=4,22)$ daha yüksek düzeyde değerlendirdikleri belirlenmiştir.

Tablo 7. Yöneticilik Tecrübesi Değişkeni T Test Sonuçları

\begin{tabular}{|c|c|c|c|c|c|c|}
\hline & & & $\begin{array}{r}\text { Var. } \mathrm{E} \\
\mathrm{Te}\end{array}$ & liği & & \\
\hline Faktör & Gruplar & $\tilde{\mathbf{x}}$ & Levene & $p$ & $t$ & $\mathbf{P}$ \\
\hline \multirow[b]{2}{*}{ YEB } & Yöneticilik Yapmış & 4,29 & \multirow[b]{2}{*}{,934 } & \multirow[b]{2}{*}{,074 } & \multirow[b]{2}{*}{2,553} & \multirow[b]{2}{*}{041} \\
\hline & $\begin{array}{l}\text { Yöneticilik } \\
\text { Yapmamış }\end{array}$ & 4,22 & & & & \\
\hline
\end{tabular}


Eğitim değişkeni (ANOVA); YAB $(, 034)$, DB $(, 038)$ ve YEB $(, 011)$ boyutları ile kadın çalışanların eğitim değişkenleri arasında anlamlı farklılıklar tespit edilmiştir. Buna göre YAB boyutunda ön lisans mezunu kadın çalışanların $(\tilde{x}=4,50)$ lisans mezunu kadın çalışanlara göre $(\tilde{x}=4,32)$ ve DB boyutunda ön lisans mezunu kadın çalışanların $(\tilde{x}=4,26)$ lisans mezunu kadın çalışanlara göre $(\tilde{X}=4,01)$ daha yüksek değerlendirdikleri belirlenmiştir. YEB boyutunda ise lisans mezunu kadın çalışanların $(\tilde{\mathrm{x}}=4,31)$ ön lisans mezunu kadın çalışanlara göre $(\tilde{\mathrm{x}}=4,24)$ daha yüksek değerlendirdikleri belirlenmiştir.

Tablo 8. Eğitim Değişkeni ANOVA Analizi Sonuçları

\begin{tabular}{|c|c|c|c|c|c|c|}
\hline \multirow[b]{2}{*}{ Faktör } & \multirow[b]{2}{*}{ Gruplar } & \multirow[b]{2}{*}{$\tilde{\mathbf{x}}$} & \multicolumn{2}{|c|}{$\begin{array}{c}\text { Var. Eşitliğ } \\
\text { Testi }\end{array}$} & \multirow[b]{2}{*}{$F$} & \multirow[b]{2}{*}{$\mathbf{P}$} \\
\hline & & & Levene & $p$ & & \\
\hline \multirow{2}{*}{ YAB } & Ön lisans & 4,50 & \multirow{2}{*}{2,972} & \multirow{2}{*}{,054 } & \multirow{2}{*}{2,575} & \multirow{2}{*}{,034 } \\
\hline & Lisans & 4,32 & & & & \\
\hline \multirow{2}{*}{ DB } & Ön lisans & 4,26 & \multirow{2}{*}{1,204} & \multirow{2}{*}{,311 } & \multirow{2}{*}{2,476} & \multirow{2}{*}{,038 } \\
\hline & Lisans & 4,01 & & & & \\
\hline \multirow{2}{*}{ YEB } & Ön lisans & 4,24 & \multirow{2}{*}{,973 } & \multirow{2}{*}{,408 } & \multirow{2}{*}{2,110} & \multirow{2}{*}{,011 } \\
\hline & Lisans & 4,31 & & & & \\
\hline
\end{tabular}

Departman değişkeni (ANOVA); DB $(, 044)$ ve YEB $(, 010)$ boyutları ile kadın çalışanların çalıştıkları departman değişkenleri arasında anlamlı farklılıklar tespit edilmiştir. Buna göre DB boyutunda kat hizmetleri $(\tilde{\mathrm{x}}=4,44)$ ve insan kaynakları $(\tilde{\mathrm{x}}=4,23)$ departmanlarında çalışan kadınların ön büro $(\tilde{\mathrm{x}}=3,78)$ ve serviste çalışan $(\tilde{\mathrm{x}}=3,76)$ kadınlara göre daha yüksek değerlendirdikleri belirlenmiştir. YEB boyutunda ise ön büro $(\tilde{x}=4,42)$ ve mutfak $(\tilde{x}=4,42)$ departmanlarında çalışan kadınların serviste çalışan $(\tilde{\mathrm{x}}=3,78)$ kadınlara göre daha yüksek değerlendirdikleri belirlenmiştir.

Tablo 9. Departman Değişkeni ANOVA Analizi Sonuçları

\begin{tabular}{|c|c|c|c|c|c|c|}
\hline & & & $\begin{array}{r}\text { Var. E } \\
\mathrm{Te}\end{array}$ & liği & & \\
\hline Faktör & Gruplar & $\tilde{\mathbf{x}}$ & Levene & $\mathrm{p}$ & $\mathbf{F}$ & $\mathbf{P}$ \\
\hline \multirow{4}{*}{ DB } & Kat Hizmetleri & 4,44 & \multirow{4}{*}{2,009} & \multirow{4}{*}{,060 } & \multirow{4}{*}{2,851} & \multirow{4}{*}{,044 } \\
\hline & İnsan Kaynakları & 4,23 & & & & \\
\hline & Ön büro & 3,78 & & & & \\
\hline & Servis & 3,76 & & & & \\
\hline \multirow{3}{*}{ YEB } & Ön büro & 4,42 & \multirow{3}{*}{2,625} & \multirow{3}{*}{,456 } & \multirow{3}{*}{2,635} & \multirow{3}{*}{,010 } \\
\hline & Mutfak & 4,42 & & & & \\
\hline & Servis & 3,78 & & & & \\
\hline
\end{tabular}

Çalışılan pozisyon değişkeni (ANOVA); YAB $(, 048)$, DB $(, 011)$ ve YEB $(, 036)$ boyutları ile kadın çalışanların çalıştıkları pozisyon değişkenleri arasında anlamlı farklılıklar tespit edilmiştir. Buna göre YAB boyutunda alt kademe yöneticilerin $(\tilde{x}=4,66)$ ve orta kademe yöneticilerin $(\tilde{x}=4,59)$ alt kademe çalışan $(\tilde{\mathrm{x}}=4,31)$ ve stajyer $(\tilde{\mathrm{x}}=4,20)$ kadın çalışanlara göre daha yüksek değerlendirdikleri belirlenmiştir. DB boyutunda alt kademe yöneticilerin $(\tilde{x}=4,49)$ ve orta kademe yöneticilerin $(\tilde{\mathrm{x}}=4,36)$ stajyer $(\tilde{\mathrm{x}}=4,20)$ ve alt kademe $(\tilde{\mathrm{x}}=4,03)$ kadın çalışanlara göre daha yüksek değerlendirdikleri belirlenmiştir. YEB boyutunda ise stajyer $(\tilde{x}=4,45)$ ve alt kademe çalışan kadınların $(\tilde{\mathrm{x}}=4,31)$ üst kademe $(\tilde{\mathrm{x}}=4,10)$ ve orta kademe yönetici olarak $(\tilde{\mathrm{x}}=3,90)$ çalışan kadınlara göre daha yüksek değerlendirdikleri belirlenmiştir. 
Tablo 10. Çalışılan Pozisyon Değişkeni ANOVA Analizi Sonuçları

\begin{tabular}{|c|c|c|c|c|c|c|}
\hline & & & $\begin{array}{r}\text { Var. E } \\
\text { Te }\end{array}$ & liği & & \\
\hline Faktör & Gruplar & $\tilde{\mathbf{x}}$ & Levene & $p$ & F & $\mathbf{P}$ \\
\hline \multirow{4}{*}{ YAB } & $\begin{array}{ll}\text { Alt } & \text { Kademe } \\
\text { Yönetici } & \\
\end{array}$ & 4,66 & \multirow{4}{*}{4,188} & \multirow{4}{*}{,063 } & \multirow{4}{*}{2,677} & \multirow{4}{*}{, 048} \\
\hline & $\begin{array}{ll}\text { Orta } & \text { Kademe } \\
\text { Yönetici } & \end{array}$ & 4,59 & & & & \\
\hline & Alt Kademe Çalışan & 4,31 & & & & \\
\hline & Stajyer & 4,20 & & & & \\
\hline \multirow{4}{*}{ DB } & $\begin{array}{ll}\text { Alt } & \text { Kademe } \\
\text { Yönetici } & \\
\end{array}$ & 4,49 & \multirow{4}{*}{2,688} & \multirow{4}{*}{,174 } & \multirow{4}{*}{3,411} & \multirow{4}{*}{,011 } \\
\hline & $\begin{array}{ll}\text { Orta } & \text { Kademe } \\
\text { Yönetici } & \\
\end{array}$ & 4,36 & & & & \\
\hline & Stajyer & 4,20 & & & & \\
\hline & Alt Kademe Çalışan & 4,03 & & & & \\
\hline \multirow{4}{*}{ YEB } & Stajyer & 4,45 & \multirow{4}{*}{1,860} & \multirow{4}{*}{ 121 } & \multirow{4}{*}{2,765} & \multirow{4}{*}{,036 } \\
\hline & Alt Kademe Çalışan & 4,31 & & & & \\
\hline & $\begin{array}{ll}\text { Üst } & \text { Kademe } \\
\text { Yönetici } & \\
\end{array}$ & 4,10 & & & & \\
\hline & $\begin{array}{ll}\text { Orta } & \text { Kademe } \\
\text { Yönetici } & \\
\end{array}$ & 3,90 & & & & \\
\hline
\end{tabular}

Yapılan fark testleri sonuçlarına göre belirlenen araştırma hipotezlerinin tümünün "kabul" edildiği sonucuna ulaşılmıştır.

\section{SONUÇ ve ÖNERILER}

Gerçekleştirilen bu çalışmanın temel amacını; Türkiye'nin Marmara Bölgesi Trakya Bölümü'nde faaliyetlerini sürdüren dört ve beş yıldızlı konaklama işletmelerinde çalışan kadınların işletmelerinde algıladıkları "Kraliçe Arı Sendromu" düzeylerinin ölçülmesi ve ilgili kadın çalışanların demografik özellikleri (medeni durum, yaş, eğitim düzeyi, departman türü, işletmedeki pozisyon, işletmede çalışma süresi ve yöneticilik tecrübesi) ile "Kraliçe Arı Sendromu" boyutları arasındaki farklılıkların belirlenmesi oluşturmaktadır. Özellikle, bu konuda bir ölçek geliştirme çalışması olması da araştırmanın önemini göstermektedir. "Kraliçe Arı Sendromu", literatürde çok sayıda çalışmaya konu olan ve özellikle kadınların bulundukları örgüt içerisinde, birlikte çalıştıkları kadınlara karşı davranışlarını etkileyen bir fenomendir.

Araştırma neticesinde elde edilen sonuçlar, turizm sektöründe "Kraliçe Arı Sendromu"nun var olduğunu göstermektedir. Derks vd., (2011a; 2011b) ve Örücü vd., (2007) çalışmalarında olduğu gibi kadın yöneticiler, kendilerine bağlı olarak çalışmakta olan kadınları kendilerine yönelik tehdit unsuru olarak değerlendirebilmektedir. "Kraliçe Arı Sendromu", hizmet sektörünün en önemli alanlarından birisi olan turizmde çalışan kadınların, kariyerleri önünde büyük bir engele neden olmaktadır. Araştırma kapsamında, turizm işletmeleri içerisindeki kadınların, birim içerisinde yaşanan çekişmelerden olumsuz yönde etkilendiği belirlenmiştir. Cooper'ın (1997) çalışmasında belirttiği üzere ifade edilen durum, kadınların yöneticilik özelliklerinin sorgulanmasına ve yetersiz olarak değerlendirilmelerine sebep olmaktadır. 
Araştırma kapsamında elde edilen sonuçlar, evli olan işgörenlerin "Kraliçe Arı Sendromu"nu sergileme tutumunun daha yüksek olduğunu göstermektedir. Dolayısıyla bu konuda elde edilen sonuçlar literatürdeki diğer çalışmalarla (Derks vd., 2011b; Öztürk ve Cevher, 2015; İmamoğlu Akman ve Akman, 2016; Şengül vd., 2019) benzerlik göstermektedir. Araştırma kapsamında genel olarak aynı seviyede çalışan işgörenler birbirlerine karşı "Kraliçe Arı Sendromu" tutumu sergilemezken, üst yöneticiler, altındaki astlara yönelik olarak, "Kraliçe Arı Sendorumu" tutumunu sergilemektedir. Dolayısıyla ilgili açılardan literatürdeki çalışmalarla Öztürk ve Cevher, (2015) benzerlikler göstermektedir.

Ellemers vd., (2004) araştırmasında belirtildiği üzere, "Kraliçe Arı Sendromu", sendroma maruz kalan kişilerin içinde bulundukları örgüte yönelik daha az bağlılık düzeyinde sahip olmaktadır. Araştırma kapsamında elde edilen sonuçlar, ilgili görüşü desteklemektedir. Ayrıca araştırma çerçevesinde elde edilen sonuçlar, Akdöl ve Menteş'in (2017) ve Meriçelli'nin (2017) çalışmalarında olduğu gibi birden fazla kadın yöneticinin bulunduğu birimlerde, çatışmanın daha fazla olduğunu göstermektedir. Yaşanılan sorunlar, kadınların bağlı bulundukları örgütten ayrılmalarına neden olabilmektedir. Cevher ve Öztürk'e (2015) "Kraliçe Arı Sendromu", çeşitli mobbing uygulamalarını bünyesinde barındıran, bilinçli ve bilinçsiz uygulamalardır. Özellikle mesleğe yeni başlayan kişilerin "Kraliçe Arı Sendromu"na maruz kalmaları, yaşadıkları mobbing olarak değerlendirmelerine neden olmaktadır.

Konaklama işletmelerinde "Kraliçe Arı Sendromu" değerlendirme ölçeği boyutları olarak Destek boyutu (DB), Yapı boyutu (YAB) ve Yeterlilik boyutu (YEB) belirlenmiştir. İlgili sonuç, literatürle uyumludur (Akman İmamoğlu ve Akman, 2016). Ölçek geliştirme kapsamında yararlanılan çalışmalar (Cooper, 1997; Ellemers vd., 2004; Örücü vd., 2007; Tanyeli 2008; Baumgartner ve Schneider 2010; Derks vd., 2011a; Derks vd., 2011b; Cevher ve Öztürk, 2015; Öztürk ve Cevher, 2015; Akman İmamoğlu ve Akman, 2016; Akdöl ve Menteş, 2017; Eren ve Aydın, 2019) ile benzer sonuçların elde edilmesi, ölçeğin güvenilir olduğunu göstermektedir. Geliştirilen ölçeğin, konuya ilişkin mevcut durumun belirlenmesine destek sağladığı düşünülmektedir.

Turizm sektörünün emek-yoğun bir yapıya sahip olması, turizmin mevsimsellik özellik sergilemesi, soyut ve somut mal ve hizmetlerin bütününden oluşması gibi etmenler, turizm sektöründe istihdamı zorlaştıran unsurlar olmakla birlikte bir de ilgili sektörde istihdam edilecek nitelikli işgücüne ulaşmanın güçlügü, sunulan mal ve hizmetin kalitesini etkileyebilmektedir. İnsanların turizm sektöründe kariyerlerini sürdürmeleri için çalıştıkları örgütlerin "huzurlu" olması son derece önemlidir.

İnsanların turizm sektöründe çok sayıda kariyer engeli olduğu dikkate alındığında, kadın yöneticilerin kadın astlarına karşı çeşitli engeller koyması, işgören bağlılığını düşürebilmekte ve işgören devir hızını da arttırmaktadır. İfade edilen durumların önüne geçilebilmesi için turizm sektöründe faaliyet gösteren işletmelere bilgilendirme eğitimleri verilmeli, liyakate dayalı terfi sisteminin uygulanması için gerekli yönlendirmeler yapılabilir. Turizm sektöründe istihdam edilen kişilerin, belirtilen konularda bilgilendirmeleriyle, kadınların turizm sektörü içerisinde doğru bir şekilde istihdamı ve kariyer ilerlemeleri sağlanabilir. Araştırmanın sınırlılığı ile ilgili olarak, konunun kendine özgü bir yapısının olması, turizmde istihdam edilen kadın çalışan ve kadın yönetici sayısı söylenebilir.

Yapılan bu araştırmanın ilgili literatüre ve sonraki çalışmalara katkı sağlayacağı düşünülmektedir. Ancak araştırma maddi kaynaklar, zaman sınırlılığı ve araştırma alanında yaşanan mevsimsel dezavantajlardan dolayı daha geniş bir örnekleme büyüklüğüne 
uygulanamamıştır. Bu sebeple gelecekteki çalışmalarda araştırmaya dâhil edilen kadın çalışanların çalıştıkları turizm işletmelerinin türleri ve örnekleme kapsamının arttırılması araştırma sonuçlarının genellenmesi ve karşılaştııılması açısından olumlu katkı sağlayacaktır. Araştırmada uygulanan ölçek nicel anlamda, ilk kez ulusal literatürde ve turizm alanında kullanılmıştır. Bu nedenle, ölçeğe yapılacak yeni eklemeler ve demografik değişkenlerde yapılacak farklı eklemeler sayesinde, kadın çalışanların "Kraliçe Arı Sendromu" düzeylerinin ölçülebilmesi mümkün olacaktır.

\section{KAYNAKÇA}

Adebayo, D. E. and Udegbe, I. B. (2004). Gender in the Boss-subordinate Relationship: A Nigerian Study, Journal of Organizational Behavior, 25: 515-525.

Akdöl, B. ve Menteş, S. A. (2017). Kadınların Yönetici Pozisyonlarında Yaşadıkları Zorluklar ve Lider Üye Etkileşiminde Cinsiyetin Rolü, Business ve Management Studies: An International Journal, 5(3): 859-879.

Akman İmamoğlu, G. ve Akman, Y. (2016). Kraliçe Arı Sendromu Bağlamında Kadın Öğretmenlerin Kadın Yöneticilere İlişkin Görüşleri, Bartın Üniversitesi Edebiyat Fakültesi Dergisi, 5(3): 748-763.

Akşit Aşık, N. (2014). Konaklama İşletmelerinde Cam Tavan Sendromu Kavramsal Bir Değerlendirme, Uluslararası Hakemli Beşeri ve Akademik Bilimler Dergisi, 3(9): 84-103.

Altunışık, R., Coşkun, R., Bayraktaroğlu, S. ve Yıldırım, E. (2007). Sosyal Bilimlerde Araştırma Yöntemleri SPSS Uygulamalı (Geliştirilmiş Beşinci Baskı). Sakarya: Sakarya Yayıncılık.

Bagilhole, B. (1993). Survivors in a Male Preserve: A Study of British Women Academics' Experiences and Perceptions of Discrimination in a UK University. Higher Education, 26: 431-447.

Baumgartner, M. S. and Schneider, D. E. (2010). Perceptions of Women in Management: A Thematic Analysis of Razing the Glass Ceiling, Journal of Career Development, 37(2): 559-576.

Baykal, E. (2018). Sosyal Kimlik Teorisi Perspektifiyle Kraliçe Arı Sendromu, Karadeniz Teknik Üniversitesi Sosyal Bilimler Enstitüsü Dergisi, 8(16): 159-175.

Blau, F. D. and DeVaro, J. (2007). New Evidence on Gender Differences in Promotion Rates: An Empirical Analysis of a Sample of New Hires, Cornell University ILR School Digital Commons @ ILR (01.07.2007). 511-550.

Biernat, M. and Fuegen, K. (2001). Shifting Standards and the Evaluation of Competence: Complexity in Gender-Based Judgment and Desecion Making, Journal of Social Issues, 57(4): 707724 .

Büyüköztürk, Ş. (2002). Faktör Analizi: Temel Kavramlar ve Ölçek Geliştirmede Kullanımı, Kuram ve Uygulamada Ĕ̆itim Yönetimi, 32: 470-483.

Camussi, E. and Leccardi, C. (2005). Stereotypes of Working Women: The Power of Expectations. Social Science Information, 44(1): 113-140. 
Cevher, E ve Öztürk, U. C. (2015). İş Yaşamında Kadınların Kadınlara Yaptı̆̆ı Mobbing Üzerine Bir Araştırma, İnsan ve Toplum Bilimleri Araştırmaları Dergisi, 4(4): 860-876.

Cooper, V. W. (1997). Homophily or Queen Bee Syndrome Female Evaluation Female Leadership, Small Group Research, 28(4): 483-499.

Davidson, M. J. and Burke, R. J. (2011). Women in Management Worldwide: Progress and Prospects A Overview, in Women in Management Worldwide: Progress and Prospects, 1-20, Marilyn J. Davidson and Ronald J. Burke, Ed., Second Edition, England: Gower Publishing Limited Wey Court East Union Road Farnham Surrey.

Derks, B., Ellemers, N., Van Laar, C. and Groot, K. (2011a). Do Sexist Organizational Cultures Create the Queen Bee?, British Journal of Social Psychology, 50: 519-535.

Derks, B., Van Laar, C., Ellemers, N. and Groot, K. (2011b). Gender-Bias Primes Elicit Queen-Bee Responses Among Senior Policewoman, Psychological Science, 22(10): 1243-1249.

Derks, B., Van Laar, C., Ellemers, N. and Raghoe, G. (2015). Extending the Queen Bee Effect: How Hindustani Workers Cope with Disadvantage by Distancing the Self from the Group, Journal of Social Issues, 71(3): 476-496.

Derks, B., Van Laar, C. and Ellemers, N. (2016). The Queen Bee Phenomenon: Why Women Leaders Distance Themselves from Junior Women, The Leadership Quarterly, 27(3): 456-479.

Durmuş, B., Yurtkoru, E. S. ve Çinko, M. (2010). Sosyal Bilimlerde SPSS'le Veri Analizi (Tıpkı Üçcüncü Basım). İstanbul: Beta Yayıncılık.

Ellemers, N., Heuvel, H., Gilder, D., Maass, A. and Bonvini, A. (2004). The Underrepresentation of Women in Science: Differential Commitment or the Queen Bee Syndrome?, British Journal of Social Psychology, 43, 315-338.

Ellemers, N., Rink, F., Derks, B. and Ryan, M. R. (2012). Women in High Places: When and Why Promoting Women into Top Positions Can Harm Them Individually or as a Group (And How to Prevent This), Research in Organizational Behaviour, 32, 163-187.

Er, O. ve Adıgüzel, O. (2015). Cam Tavan Gölgesindeki Kraliçe Arılar: Kadınların Kariyer İlerlemelerinde Karşılaştıkları Engeller ve Etkili Liderlik, Recep Tayyip Erdoğan Üniversitesi Sosyal Bilimler Dergisi. 2: 163-175.

Eren, R. and Aydın, A. (2019). Perceptions and Attitudes of Culinary Students Towards Food and Beverage Industry in Turkey, Journal of Culinary Science and Technology, https://www.tandfonline.com/doi/pdf/10.1080/15428052.2019.1640155?casa_token=iPh36bn1Yqc AAAAA:KUMaZ1HBpfczdsIewun8UZANRygfZR81sTveDeDG1rtkPm7ywE9cLY1LnuU5sinTq TY9hm0mVq7, 1-25.

Ezell, H. F., Odewahn, C. A. and Sherman, J. D. (1981). The Effects of Having Been Supervised by a Woman on Perceptions of Female Managerial Competence, Personnel Psychology, 34: 291-299. 
İlban, O. M. (2008). Seyahat Acenta Yöneticilerinin Destinasyon Marka İmajı Algıları Üzerine Bir Araştırma. Ege Akademik Bakış, 8 (1): 121- 152.

Kara, H., Tokat, B. ve Doğru, A. (2014). Örgütsel Ortamda Kadın İşgörenlere Yönelik Geliştirilen Cinsiyet İkilemi Tutumlarının Bir Sonucu Olarak Cam Tavan Sendromunun Sınanması, Uluslararası Hakemli ve Beşeri Akademik Bilimler Dergisi, 3(8): 125-138.

Karakuş, H. (2014). Kraliçe Arı Sendromu-Pembe Taciz, Akademik Sosyal Araştırmalar Dergisi, 2(5): 334-356.

Karatepe, S. ve Arıbaş, N. N. (2017). İş Hayatında Kadın Yöneticilere İlişkin Cinsiyet Ayrımcılığı: Türkiye İçin Bir Değerlendirme, Yaşam Dergisi, 31(Özel Sayı): 7-23.

Mavin, S. (2006). Venus Envy: Problematizing Solidarity Behaviour and Queen Bees, Women in Management Review, 21(4): 264-276.

Mavin, S. (2008). Queen Bees, Wannabees and Afraid to Bees: No More 'Best Enemies' for Women in Management?, British Journal of Management, 19: 75-84.

Mavin, S. and Grandy, G. (2012). Doing Gender Well and Differently in Management, Gender in Management: An International Journal, 27(4): 218-231.

Meriçelli, F. (2017). Kadınların Okul Yöneticisi Olmasının Önündeki Engeller, Yayınlanmamış Yüksek Lisans Tezi, Eskişehir Osmangazi Üniversitesi, Eskişehir.

Örücü, E., Kılıç, R. ve Kılıç, T. (2007). Cam Tavan Sendromu ve Kadınların Üst Düzey Yönetici Pozisyonuna Yükselmelerindeki Engeller: Balıkesir İli Örneği, Yönetim ve Ekonomi Dergisi, 14(2): 117-135.

Öztürk, U. C. ve Cevher, E. (2015). İşyerinde Tacizin Pembe Hali: Kadınların Kadınlara Uyguladığı Mobbing, Uludă̆ Üniversitesi İktisadi ve İdari Bilimler Fakültesi Dergisi, 34(1): 151-174.

Staines, G., Tavris, C. and Jayaratne, E. (1974). The Queen Bee Syndrome, Psychology Today, 7(8): 55- 60.

Şengül, H. Çınar, F. and Bulut, A. (2019). The Perception Queen Bee Phenomenon in Nurses; Qualitative Study in Health Sector, Nigerlan Journal of Clinical Practice, 22(7): 906-912.

Tabachnick, B. G. and Fidell, L. S. (2013). Using Multivariate Statistics. Boston: Pearson.

Tanyeli, Ç. (2008). Örgüt Kültürü İçinde Cinsiyet Ayrımcıllğı Algılamasının Kadın Kariyeri Üzerine Etkileri: Kavramsal ve Uygulamalı Bir Araştırma. Yayınlanmamış Yüksek Lisans Tezi, Selçuk Üniversitesi, Konya.

Ural, A. ve Kılıç, İ. (2005). Bilimsel Araştırma Süreci ve SPSS ile Veri Analizi, Ankara: Detay Yayıncilik. 
Van Knippenberg, D., Van Dick. R. and Tavares, S. (2007). Social Identity and Social Exchange: Identification, Support, and Withdrawal from the Job, Journal of Applied Social Psychology, 37(3): 457- 477.

Virick, M. and Greer, C. R. (2012). Gender Diversity in Leadership Succession: Preparing for the Future, Human Resource Management, 51(4), 575-600.

Yazıcıoğlu, Y. ve Erdoğan, S. (2007). SPSS Uygulamalı Bilimsel Araştırma Yöntemleri (Genişletilmiş İkinci Baskl), Ankara: Detay Yayıncilı. 